\title{
Tumor Sinus Paranasal Dengan Perluasan Intrakranial dan Metastasis ke Paru
}

\author{
Sukri Rahman, M. Abduh Firdaus
}

\section{Abstrak}

Keganasan hidung dan sinus paranasal (sinonasal) merupakan tumor yang jarang ditemukan, hanya merupakan $1 \%$ dari seluruh tumor ganas di tubuh dan $3 \%$ dari keganasan di kepala dan leher. Diagnosis secara dini dan pengobatan sampai saat ini masih merupakan tantangan. Pasien dengan tumor sinonasal biasanya datang pada stadium yang sudah lanjut, dan umumnya sudah meluas ke jaringan sekitarnya. Tidak jarang keluhan utama pasien justru akibat perluasan tumor seperti keluhan mata dan kepala dan bahkan gejala akibat metastsis jauh. Prognosis keganasan ini umumnya buruk. Hal ini karena anatomi sinus yang merupakan rongga yang tersembunyi dalam tulang, yang tidak akan dapat dideteksi dengan pemeriksaan fisik biasa dan sering asimptomatik pada stadium dini serta lokasinya yang berhubungan erat dengan struktur vital. Dilaporkan satu kasus tumor sinus paranasal pada seorang lali-laki berusia 52 tahun yang telah mengalami perluasan ke intrakranial dan metastasis ke paru.

Kata kunci: tumor sinonasal, perluasan intrakranial, metastasis paru.

\begin{abstract}
Malignancies of the nasal cavity and paranasal sinuses (sinonasal) are rare, comprising only $1 \%$ of all human malignancies and only $3 \%$ of those arising in the head and neck. Early diagnosis and treatment are still a challenge. A patient with sinonasal tumors usually comes at the advanced stage, and generally has spread to surrounding tissue. Not infrequently the patient's main complaint due to the expansion of the tumors such as eye or head complaints and sometimes even result of distant metastases. It has been associated with a poor prognosis. This is because the anatomy of the sinuses, which is a hidden cavity in the bone, which can not be detected by regular physical examination, tend to be asymptomatic at early stages, and located close anatomic proximity to vital structures. A case of paranasal sinus tumors in a 52-year-old man who has experienced intracranial expansion and pulmonary metastases is reported.
\end{abstract}

Keywords: sinonasal tumor, intracranial expansion, pulmonary metastases.

Affiliasi penulis : Bagian Telinga Hidung Tenggorok Bedah Kepala Leher (THT-KL) Fakultas Kedokteran Universitas Andalas/ RSUP. Dr. M. Djamil Padang

Korespondensi : Sukri Rahman Email : sukrirahman@fk.unand.ac.id Telp: 0751-810900

\section{Pendahuluan}

Tumor hidung dan sinus paranasal (sinonasal) merupakan tumor yang jarang ditemukan dan sampai saat ini diagnosis secara dini dan pengobatan masih merupakan tantangan. Gejala dan tandanya hampir sama dengan proses inflamasi daerah hidung dan sinus, sehingga pasien biasanya datang sudah dalam stadium lanjut. Keganasan ini juga merupakan tumor yang sulit untuk diobati sehingga prognosisnya sering buruk. Keadaan ini disebabkan lokasi anatomi hidung dan sinus paranasal yang berdekatan dengan strukturstruktur vital seperti dasar tengkorak, otak, mata dan arteri karotis. ${ }^{1,2,3,4,5}$

Kegansan hidung dan sinus paranasal hanya merupakan $1 \%$ dari seluruh tumor ganas di tubuh, dan $3 \%$ dari keganasan di kepala dan leher, sinus maksila merukan tempat tersering (60-80\%) diikuti kavum nasi $20-30 \%$ dan sinus etmoid $\pm 15 \%$, sedangkan sinus frontal dan sfenoid sangat jarang dijumpai (kurang dari $1 \%),{ }^{1,2}$ dengan perbandingan laki-laki dan perempuan $2: 1.2$
Data di bagian THT FKUI/RSCM selama 10 tahun, keganasan ini menduduki urutan ke tiga terbanyak setelah karsinoma nasofaring dan limfoma malignum non Hodgkins di kepala leher, ${ }^{2}$ sedangkan di RS.Dr.M. Djamil belum ada penelitian, namun dari penelusuran rekam medis pasien, selama 6 bulan sejak 1 Januari 2006 bagian THT-KL RS.Dr. M. Djamil telah merawat 10 kasus baru keganasan hidung dan sinus paranasal, selama tahun 2004 dan 2005 merawat 37 kasus baru keganasan hidung dan sinus paranasal.

Beberapa penelitian epidemiologi menunjukkan adanya hubungan antara tingginya insiden keganasan ini dengan terpapar bahan-bahan kimia karsinogen dan serbuk kayu. ${ }^{1,2,6}$

\section{Epidemiologi dan Etiologi}

Keganasan sinonasal merupakan keganasan yang jarang terjadi, hanya $1 \%(0,2-1 \%)$ dari seluruh keganasan di tubuh, dan 3\% dari keganasan di kepala dan leher.5,7 Keganasan sinonasal lebih sering pada laki-laki dengan perbandingan laki-laki dengan perempuan 2:1. Keganasan ini sering terdiagnosis pada usia 50 sampai 70 tahun.2'5

Lebih kurang 60\% keganasan ini berasal dari sinus maksila, dikuti kavum nasi $20-30 \%$, sinus etmoid $10-15 \%$ dan sinus sfenoid dan sinus frontal 
1\%. Bila tumor kavum nasi tidak dimasukkan maka, $77 \%$ berasal dari sinus maksila, $22 \%$ dari sinus etmoid dan $1 \%$ dari sfenoid dan frontal. Keganasan ini dengan angka yang tinggi ditemukan di Jepang, China dan India.7

Penyebab pasti belum diketahui, namun kontak dengan debu kayu diketahui merupakan faktor risiko utama yang berhubungan dengan keganasan ini. Mulculnya keganasan biasanya sekitar 40 tahun setelah kontak pertama. Peningkatan risiko keganasan ini juga didapatkan pada pekerja pemurnian nikel dan pabrik pigmen kromat. Disamping itu, dilaporkan bahwa kontak dengan formaldehid, diisoprofil sulfat, dikloroetil sulfide dan merokok juga meningkatkan risiko timbulnya keganasan ini.7

\section{Anatomi}

Sinus paranasal dan rongga hidung berbatasan dengan struktur-struktur vital yang akan terlibat apabila tumor telah meluas. Kavum nasi merupakan saluran nafas yang terletak paling atas dan mukosanya terdiri dari kombinasi epitel kubik dan epitel bertingkat toraks bersilia. Mukosa hidung terdiri dari kelenjar mukus, kelenjar ludah minor, melanosit dan epitel penghidu di bagian superior. Rongga hidung di garis tengah dibagi oleh septum. Batas superior dari kavum nasi adalah sinus etmoid dan bagian inferior berbatasan dengan palatum durum. Dinding lateral rongga hidung juga merupakan dinding medial sinus maksila. Sinus sfenoid berada di superior dan posterior dari rongga hidung. $5^{8}$ (gambar 1 )

Kompleks etmoid terdiri dari 3-18 sel yang berada diantara orbita. Sisi kanan dan sisi kiri dihubungkan oleh fossa kribriformis. Fossa kribriformis merupakan salah satu landmark pada penentuan stadium tumor. Kerusakan fossa ini akan menyebabkan perluasan langsung tumor ke fossa kranial anterior. Lamina papirasea merupakan dinding lateral etmoid, yang membatasinya dengan orbita. Kerusakan dinding ini akan menyebabkan perluasan tumor ke orbita, dan harus menjadi pertimbangan pada saat dilakukan tindakan operasi. Atap etmoid dibentuk oleh fovea etmoidalis, yang merupakan bagian dasar terkorak yang tipis.7

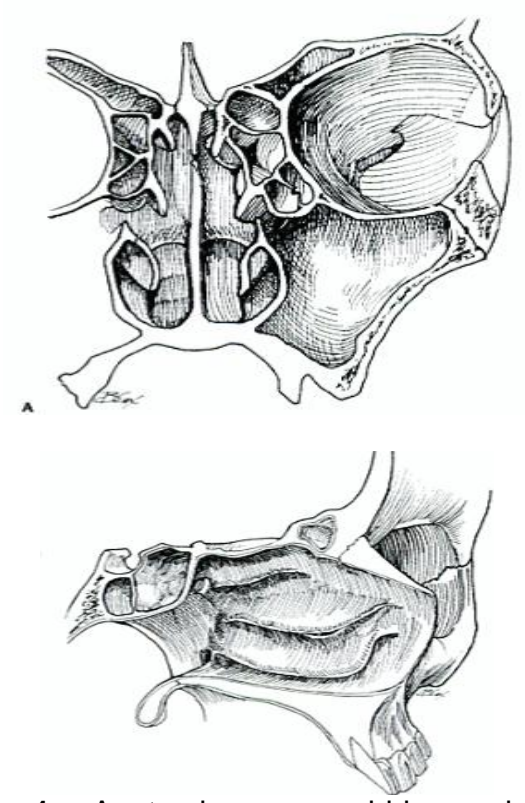

Gambar 1. Anatomi rongga hidung dan sinus paranasal.9
Sinus maksila dibagi menjadi dua bagian oleh garis imajiner yang ditarik dari kantus medial ke angulus mandibula (Öhngren line) menjadi suprastruktur dan infrastruktur. Tumor yang berasal superior dari garis ini berhubungan dengan prognosis yang lebih buruk karena berdekatan dengan mata, fossa pterigopalatina dan fossa infratemporal, sehingga penyebarannya ke fossa kranial dan organ sekitar lebih mudah. ${ }^{9}$ (gambar 2 ).

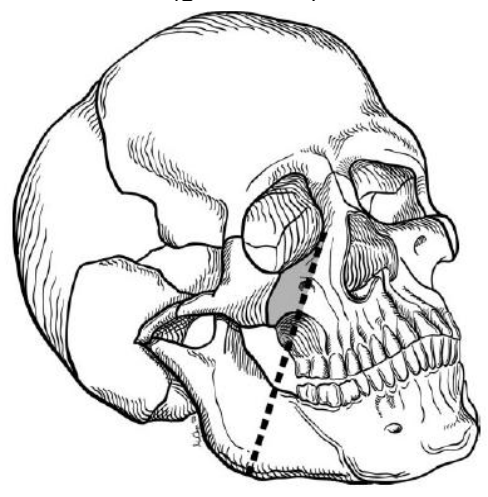

Gambar 2. Ohngren line. ${ }^{5}$

Keganasan pada sinus sphenoid biasanya unresectable karena letak anatominya yang rumit. Nervus optikus, arteri karotis dan sinus kavernosus sangat dekat dengan sinus ini, bahkan kadangkadang mengalami dehiscent. 9

Meskipun tumor di rongga hidung dan sinus paranasal memiliki pertumbuhan lokal yang ekstensif, namun penyebaran melalui aliran limfe dan darah jarang terjadi.9 Tumor yang lanjut dapat meluas ke kelenjar getah bening retrofaring, buccinator, submandibula dan jugular superior. Metastasis jauh paling sering ke paru. ${ }^{\text {to }}$

\section{Stadium}

Penilaian stadium tumor menggunakan klasifikasi AJCC (American Joint Committee on Cancer) edisi ke-6 tahun 2002, yang mengklasifikasikan tumor berdasarkan ukuran tumor primer $(\mathrm{T})$, metastasis kelenjar getah bening regional (N) dan metastasis jauh (M).

Penentuan tumor primer bersadarkan inspeksi, palpasi dan pemeriksaan neurologi saraf kranial. Pemeriksaan dengan endoskopi dianjurkan. Pemeriksaan pencitraan baik Computed Tomography scan (CT scan) atau Magnetic Resonance Imaging (MRI) diperlukan untuk mendapatkan stadium yang akurat sebelum pengobatan. ${ }^{11}$

Penilaian pembesaran kelenjar getah bening leher dilakukan dengan palpasi dan pencitraan, sedangkan metastasis jauh ditentukan dengan berbagai pemeriksaan seperti radiologi, kimia darah dan pemeriksaan lain sesuai indikasi.

Klasifikasi menurut AJCC 2002 sebagai berikut:

Tumor Primer (T)

TX Tumor primer tidak dapat dinilai

T0 Tidak terdapat tumor primer

Tis Carcinoma in situ

Sinus maksila

T1 Tumor terbatas pada mukosa sinus maksila, tidak terdapat erosi atau destruksi tulang.

T2 Tumor menyebabkan erosi atau destruksi tulang termasuk perluasan ke palatum durum, dan/ 
atau meatus medius namun tidak terdapat perluasan ke dinding posterior sinus maksila dan fossa pterigoid.

T3 Tumor telah mengenai tulang dinding posterior sinus maksila, jaringan subkutan, dinding medial atau lantai orbita, fossa pterigoid, sinus etmoid.

T4a Tumor telah mengenai orbita anterior, kulit pipi, pterygoid plates, fossa infratemporal, fossa kribriformis, sinus sfenoid atau sinus frontal.

T4b Tumor telah mengenai apeks orbita, dura, otak, fossa kranial media, saraf kranial selain $\mathrm{N}$. Maksilaris (V2), nasofaring atau clivus.

Rongga hidung dan sinus etmoid

T1 Tumor terbatas pada satu sisi dengan atau tanpa invasi ke tulang.

T2 Tumor telah mengenai dua sisi dengan atau tanpa perluasan ke jaringan sekitar di kompleks nasoetmoid dengan atau tanpa invasi tulang.

T3 Tumor telah meluas ke dinding medial atau lantai orbita, sinus maksila, palatum atau fossa kribriformis.

T4a Tumor telah mengenai orbita anterior, kulit hidung atau pipi, perluasan minimal ke fossa kranial anterior, pterygoid plates, sinus sfenoid atau sinus frontal.

T4b Tumor telah mengenai apeks orbita, dura, otak, fossa kranial media, saraf kranial selain N.V2, nasofaring atau clivus.

Metastasis ke kelenjar getah bening regional $(\mathrm{N})$

NX Pembesaran kelenjar getah bening (KGB) regional tidak dapat dinilai.

N0 Tidak terdapat pembesaran KGB

N1 Metastasis ke KGB singel ipsilateral dengan diameter terpanjang $\leq 3 \mathrm{~cm}$.

N2 Metastasis ke KGB singel ipsilateral lebih dari 3 $\mathrm{cm}$ tapi tidak lebih dari $6 \mathrm{~cm}$, atau multiple ipsilateral $\leq 6 \mathrm{~cm}$ atau bilateral atau kontralateral $\leq 6 \mathrm{~cm}$.

N2a Metastasis ke KGB singel ipsilateral lebih dari 3 $\mathrm{cm}$ tapi tidak lebih dari $6 \mathrm{~cm}$.

N2b Metastasis ke KGB multipel ipsilateral $\leq 6 \mathrm{~cm}$.

N2c Metastasis ke KGB bilateral atau kontralateral $\leq 6$ $\mathrm{cm}$.

N3 Metastasis ke KGB dengan diameter terpanjang > $6 \mathrm{~cm}$.

Metastasis jauh(M)

MX Metastasis jauh tidak dapat ditentukan.

M0 Tidak terdapat metastasis jauh.

M1 Terdapat metastasis jauh.

\section{Stadium tumor}

$\begin{array}{llll}\text { Stadium 0 } & \text { Tis } & \text { N0 } & \text { M0 } \\ \text { Stadium I } & \text { T1 } & \text { N0 } & \text { M0 } \\ \text { Stadium II } & \text { T2 } & \text { N0 } & \text { M0 } \\ \text { Stadium III } & \text { T3 } & \text { N0 } & \text { M0 } \\ & \text { T1 } & \text { N1 } & \text { M0 } \\ & \text { T2 } & \text { N1 } & \text { M0 } \\ \text { Stadium IVA } & \text { T3 } & \text { N1 } & \text { M0 } \\ & \text { T4a } & \text { N0 } & \text { M0 } \\ & \text { T4a } & \text { N1 } & \text { M0 } \\ & \text { T1 } & \text { N2 } & \text { M0 } \\ & \text { T2 } & \text { N2 } & \text { M0 } \\ & \text { T3 } & \text { N2 } & \text { M0 } \\ & \text { T4a } & \text { N2 } & \text { M0 }\end{array}$

Stadium IVB T4b setiap N M0

$\begin{array}{lll} & \text { Setiap T } & N 3 \quad M 0 \\ \text { Stadium IVC } & \text { Setiap T } & \text { setiap N } M 1\end{array}$

Diagnosis
Diagnosis ditegakkan berdasarkan anamnesis, pemeriksaan fisik dan penunjang. Pemeriksaan nasoendoskopi dan sinuskopi dapat menemukan tumor dalam stadium dini. CT Scan merupakan sarana terbaik dalam melihat perluasan tumor dan destruksi tulang. ${ }^{12}$ Foto polos paru diperlukan untuk melihat metastasis tumor ke paru. Diagnosis pasti ditegakkan berdasarkan pemeriksaan histopatologi. ${ }^{1,} 12$

\section{Gejala Klinis}

Gejala tergantung asal tumor primer dan arah perluasannya, tumor dalam sinus maksila biasanya tanpa gejala. Gejala timbul setelah tumor telah mendestruksi tulang dan meluas ke kavum nasi, rongga mulut, pipi atau orbita.12

Berdasarkan perluasan tumor gejala dapat dikategorikan sebagai :12

1. Gejala nasal, berupa obstruksi hidung unilateral dan rinore, kadang disertai darah atau epistaksis. Desakan pada hidung menyebabkan deformitas.

2. Gejala orbital, perluasan ke arah orbita dapat menimbulkan gejala diplopia, proptosis, oftalmoplegia, gangguan visus dan epifora. Sabharwal KK dkk ${ }^{13}$ yang mengevaluasi CT scan pasien dengan proptosis, mendapatkan sebagian besar proptosis akibat keganasan. Keganasan pada sinus maksila merupakan penyebab terbanyak di luar tumor mata.

3. Gejala oral, menimbulkan penonjolan atau ulkus di palatum atau di prosesus alveolaris, sering nyeri gigi sebagai gejala awal yang membawa pasien ke dokter

4. Gejala fasial, perluasan tumor ke anterior menimbulkan penonjolan pada pipi, disertai nyeri, anestesia atau parastesia.

5. Gejala intrakranial, perluasan ke intrakranial menyebabkan sakit kepala yang hebat, oftalmoplegi, gangguan visus, kadang dapat timbul liquore serta mengenai saraf-saraf kranial.

\section{Pemeriksaan Fisik}

Pemeriksaan kepala dan leher yang lengkap harus dilakukan. Pemeriksaan dilakukan meliputi daerah sinonasal, mata, saraf kranial dan nasoendoskopi untuk menilai adanya masa tumor. Meskipun tidak patognomonis, kebas atau hipostesia di infraorbita (N.V2) atau supraorbita (N.V3) harus dicurigai adanya perluasan suatu keganasan. Selain itu tanda lain yang dapat ditemukan berupa proptosis, kemosis, gangguan fungsi otot ektraokuler, penonjolan massa di pipi, massa di ginggiva atau ginggivobukal serta kelainan pada gigi atas.

Meskipun jarang ditemukan, pemeriksaan kelenjar getah bening harus dilakukan. Cantù $\mathrm{G}$ dkk $^{14}$ melaporkan dari 305 kasus tumor ganas sinus etmoid dan 399 kasus tumor ganas sinus maksila mendapatkan pembesaran KGB leher masing-masing $1,6 \%$ dan $8,3 \%$.

Tidak jarang pasien datang dengan keluhan akibat metastasis jauh, sehingga pemeriksaan adanya metastasis jauh diperlukan. Salem L dkk seperti dikutip Smith GA dkk ${ }^{15}$ mendapatkan metastasis ke paru 2,6\% dan metastasis ke tulang $1,94 \%$. New GB seperti dikutip Smith GA dkk15 juga melaporkan bahwa paru merupakan lokasi metastasis jauh yang paling sering. Metastasis jauh juga dapat terjadi ke pleura, hepar, perikardium, ginjal, limpa dan tulang belakang. 15 


\section{Pemeriksaan Radiologi}

Pemeriksaan radiologi merupakan bagian yang sangat penting pada diagnosis, staging dan follow up keganasan sinonasal. Pemeriksaan CT scan memberikan gambaran yang baik mengenai lokasi dan perluasan tumor, CT scan dapat menentukan adanya erosi atau destruksi tulang. CT scan dengan kontras akan memberikan gambaran perluasan tumor ke organ sekitarnya.5

Di sisi lain $M R I$, memberikan gambaran yang lebih jelas batas tumor dengan jaringan lunak di sekitarnya. MRI sangat membantu dalam menentukan perluasan tumor ke orbita, dura, otak, arteri karotis dan sinus kavernosus. ${ }^{5}$

Satu laporan yang membandingkan $C T$ scan dengan $M R I$, medapatkan bahwa $M R I$ lebih superior untuk menilai perluasan tumor disamping juga dapat membedakan massa tumor dari sekret atau mukosa yang mengalami inflamasi. ${ }^{16}$

\section{Biopsi}

Apabila lokasi tumor telah dapat diidentifikasi, selanjutnya dibutuhkan pemeriksaan histopatologi jaringan. Biopsi jaringan dilakukan dengan teknik yang paling tidak invasif tetapi mendapatkan jaringan yang cukup representatif untuk diperiksa. Menghindari biopsi terbuka dengan alasan 1) akan menyebabkan gangguan keutuhan struktur anatomi dan batas tumor, 2) kemungkinan sel tumor mengkontaminasi jaringan normal dan 3) menyebabkan lokalisasi tumor dan batas-batas tumor terganggu yang menyulitkan pada saat operasi. ${ }^{5}$

Pendekatan endoskopi melalui hidung (nasoendoskopi) merupakan teknik yang optimal untuk biopsi tumor sinonasal. Kelebihan teknik ini adalah visualisasi yang lebih baik, morbiditas yang minimal, perubahan pada jaringan tumor dan organ sekitar minimal. Tumor kecil di dinding lateral sinus maksila dapat dicapai dengan melakukan antrostomi meatus medius dan visualisasi dengan endoskop $30^{\circ}$ atau $70^{\circ}$, biopsi dilakukan dengan forseps jerapah.5

Apabila tumor terbatas pada kavum nasi, biopsi lokal di poliklinik dapat dilakukan dengan memastikan sebelumnya bahwa tidak ada hubungan dengan cairan serebrospinal dan tidak mengandung vaskularisasi yang banyak. Pada tumor dengan vaskularisasi yang banyak, diperlukan pemeriksaan pencitraan tambahan sebelum dilakukan biopsi.5

Pada kasus tumor sinus maksila yang tidak dapat dicapai melalui hidung, biopsi dilakukan dengan punksi fossa kanina dan dengan bantuan endoskop.5

\section{Histopatologi}

Karsinoma sel skuamosa merupakan gambaran histopatologi yang paling sering pada keganasan sinonasal (lebih dari $80 \%$ kasus). Disamping karsinoma sel skuamosa, keganasan sinonasal juga dapat berupa adenokarsinoma, adenoid sistik karsinoma, melanoma maligna, neuroblastoma olfaktori, karsinoma tidak berdiferensiasi dan limfoma serta sarkoma.5.7

\section{Penatalaksanan}

Pilihan terapi pada keganasan sinonasal bersifat individual. Ada beberapa hal yang harus dipertimbangkan pada pemilihan terapi yaitu 1) histopatologi tumor, 2) stadium tumor, 3) kemungkinan dapat direseksi secara komplit, 4) keadaan umum pasien, 5) morbiditas yang ditimbulkan dan risiko yang mungkin terjadi, 6) kemungkinan rekonstruksi dan fungsi setelah operasi, 7) keadaan sosioekonomi pasien, 8) kemampuan ahli bedah dan 10) harapan pasien. 5

Usaha kuratif hanya memungkinkan pada tumor yang dapat diangkat secara komplit. Pada kasus ini pengobatan dilakukan dengan pengangkatan tumor secara lengkap tanpa terapi tambahan. Namun kasus keganasan sinonasal umumnya datang dengan stadium yang lanjut, sehingga membutuhkan terapi multi modalitas. 5

Operasi pengangkatan tumor dan radioterapi masih merupakan modalitas utama. Namun demikian beberapa penulis melaporkan penggunaan kemoterapi dan radiasi memberi manfaat pada keganasan yang lebih lanjut. Terapi paliatif merupakan tujuan utama pada kasus yang sudah mengalami perluasan, unresectable, metastasis jauh dan keadaan fisik yang buruk. Untuk tujuan ini radioterapi dan/ atau kemoterapi merupakan modalitas yang sering digunakan untuk mengurangi morbiditas lokal.5,17,18

Berbagai teknik pembedahan dilakukan untuk pengangkatan tumor sinonasal. Jenis operasi yang dilakukan tergantung pada lokasi dan perluasan tumor. Tumor yang berasal dari sinus maksila diangkat dengan maksilektomi. Beberapa jenis maksilektomi dengan terminologi yang beragam telah dilaporkan, namun secara umum dapat dikelompokkan menjadi maksilektomi terbatas, maksilektomi subtotal dan maksilektomi total.5

Maksilektomi terbatas merupakan teknik yang paling sering dilakukan. Maksilektomi terbatas adalah pengangkatan satu dinding dari sinus maksila, biasanya dinding medial atau lantai sinus maksila. Maksilektomi medial salah satu bagian dari teknik ini dilakukan pada tumor yang terbatas pada dinding medial sinus maksila, tumor kavum nasi dan sinus etmoid. Pada teknik ini semua dinding medial sinus maksila, lamina papirasea dan sinus etmoid diangkat.5

Tumor yang lebih luas diangkat dengan maksilektomi subtotal yaitu tindakan mengangkat paling tidak dua dinding sinus maksila termasuk palatum durum. Sedangkan maksilektomi total merupakan tindakan yang jarang dilakukan yaitu pengangkatan semua sinus maksila. Eksenterasi orbita sering dilakukan pada maksilektomi total, yaitu pada $71 \%$ kasus. 5

\section{Prognosis}

Prognosis keganasan sinus paranasal pada umumnya kurang baik, karena sebagian besar pasien datang pada stadium lanjut. Sampai beberapa dekade terakhir belum tampak peningkatan yang bermakna terhadap angka bertahan hidup pada seluruh keganasan hidung dan sinus paranasal. Angka bertahan hidup 5 tahun rata-rata untuk seluruh keganasan sinus maksila antara $20-50 \%$, hal yang sama juga berlaku untuk sinus paranasal yang lain. ${ }^{2,5}$ Popović D dkk18 melaporkan angka bertahan hidup 5 tahun untuk keganasan hidung, sinus maksila dan etmoid berturut-turut 45,38 , dan $13 \%$.

Terdapatnya metastasis ke KGB dan metastasis jauh merupakan faktor yang memperburuk prognosis pasien. $14,19,20$ 


\section{Laporan Kasus}

Seorang pasien laki-laki umur 52 tahun pada tanggal 6 Maret 2006 dikonsulkan dari ruang rawat mata RS. Dr. M. Djamil Padang dengan diagnosis protusio bulbi ec suspek tumor retroorbita dengan diagnosis banding tumor sinus paranasal.

Dari anamnesis diketahui bahwa penonjolan mata kanan yang dirasakan sejak 2 bulan yang membawa pasien berobat ke bagian mata. Disamping itu pasien juga mengeluh penglihatan ganda sejak 1 bulan terakhir. Hidung kanan tersumbat sejak 2 bulan, tidak terdapat riwayat keluar darah dari hidung dan mulut. sejak satu bulan sebelumnya pasien sering merasakan nyeri kepala yang berat yang tidak hilang dengan obat nyeri kepala yang dijual bebas. Rasa kebas di pipi kanan sebenarnya sudah dirasakan pasien sejak 3 bulan.

Sesak nafas tidak menciut dan tidak dipengaruhi posisi tidur dan batuk-batuk dirasakan terutama sejak 3 bulan terakhir, kadang-kadang disertai batuk berdahak bercampur darah. Suara serak tidak ada, telinga berdenging tidak ada, benjolan di leher tidak ada, gigi kanan atas sering dirasakan nyeri terutama sejak 1 bulan terakhir. Berat badan mengalami penurunan terutama 6 bulan terakhir.

Pasien adalah seorang petani, tidak pernah bekerja pada pekerjaan yang behubungan dengan serbuk kayu, logam atau cat. Pasien merokok sejak remaja lebih kurang satu bungkus perhari dan sudah berhenti sejak 18 tahun yang lalu. Pernah mendapat pengobatan tuberkulosis paru 18 tahun yang lalu dan sudah dinyatakan sembuh, tidak ada riwayat penyakit lain. Dalam keluarga tidak ada riwayat penyakit keganasan.

Pada pemeriksaan didapatkan keadaan umum lemah, kesadaran komposmentis, kooperatif, tidak demam.

Pada pemeriksaan hidung luar, tidak ditemukan deformitas, tidak tampak massa dan tidak terdapat penonjolan di pipi. Pada pemeriksaan rinoskopi anterior dan nasoendoskopi, kavum nasi sempit, tampak pendorongan dinding lateral hidung kanan ke arah septum, sehingga tidak ada celah antara konka dengan septum, tidak tampak massa tumor. Pemeriksaan rinoskopi posterior ditemukan adanya massa tumor pada koana kanan dan dinding lateral hidung kanan. Hidung kiri dalam batas normal. Tidak terdapat penonjolan di palatum dan rongga mulut. Pemeriksaan Telinga dan tenggorok tidak didapatkan kelainan. Tidak terdapat gangguan buka mulut. Tidak terdapat pembesaran kelenjar getah bening leher.

Pada pemeriksaan mata didapatkan Visus OD : 6/12, OS : 6/20, terdapat protusio bulbus okuli dekstra, gerak bulbus okuli dekstra terbatas dan terdapat diplopia.

Pada pemeriksaan laboratorium darah didapatkan Hemoglobin 13,4 gr/dl, Leukosit 14500 $/ \mathrm{mm}^{3}$, Trombosit $499000 / \mathrm{mm}^{3}$, Hitung Jenis 0/2/4/70/20/4, Ureum 19 mg\%, Kreatinin 0,7 mg\%, SGOT $18 \mathrm{mg} \%$, SGPT $11 \mathrm{mg} \%$.

Pada pemeriksaan CT scan orbita didapatkan hasil dengan kesan tumor (ganas) sinus maksilaris dektra dengan perluasan dan infiltrasi ke intrakranial. (gambar 3). Pada röntgen toraks postero anterior didapatkan kesan metastase (lympoid type) (gambar 4).

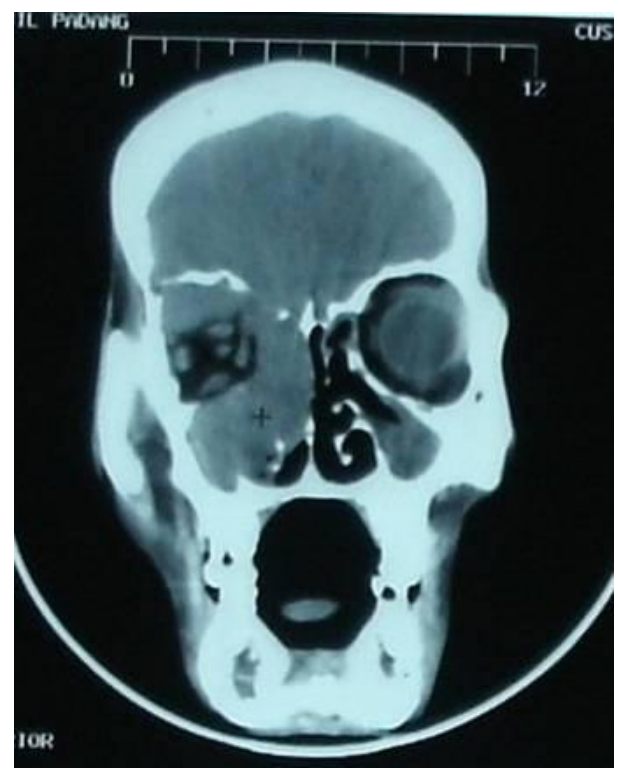

Gambar 3. CT Scan potongan koronal

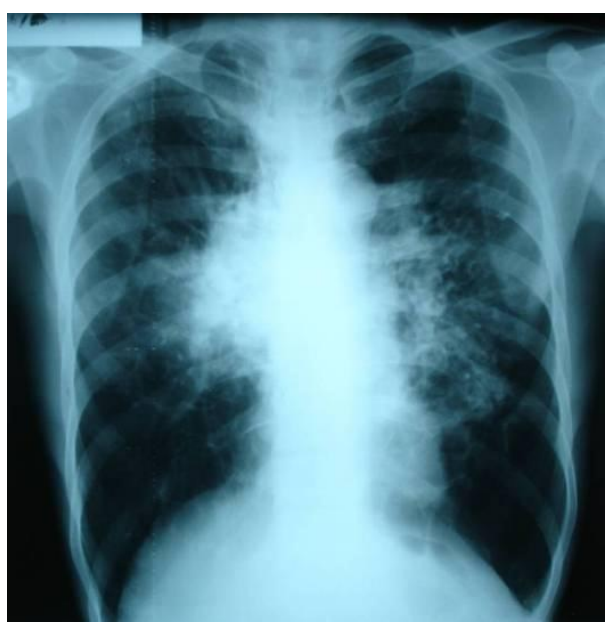

Gambar 4. Rontgen toraks PA

Saat itu ditegakkan diagnosis kerja tumor sinus paranasal dekstra dengan perluasan intrakranial dan metastasis ke paru, direncanakan untuk dilakukan biopsi.

Dilakukan konsultasi dengan bagian Penyakit dalam untuk toleransi tindakan biopsi. Dari konsultasi ini selain diagnosis awal, juga ditemukan adanya bronkopneumonia dupleks dan VES frekuens, serta dianjurkan untuk menunda tindakan sampai keadaan jantung paru baik, pemberian Oksigen 2 liter/menit, Cefotaksim 2x 1 gr IV minimal 10 hari, kordaron 2x200 mg, ambroxol sirup 3 kali $30 \mathrm{mg}$ dan parasetamol bila demam. Konsultasi juga dilakukan dengan bagian paru, dan pasien dirawat bersama bagian mata, paru dan penyakit dalam.

Selama perawatan keadaan umum semakin lemah, sesak nafas bertambah, nyeri kepala semakin berat, demam disertai adanya hemoptisis masif. Pada tanggal 13 Maret 2006 pasien meninggal setelah mengalami hemoptisis masif dan syok. Kontrol dan penatalaksanaan intensif telah dilakukan sejak dua hari sebelumnya. 


\section{Diskusi}

Telah dilaporkan satu kasus Tumor sinus paranasal dekstra dengan perluasan intrakranial dan metastasis ke paru pada seorang pasien laki-laki umur 52 tahun yang datang dengan keluhan utama mata kanan menonjol dirasakan sejak 2 bulan sebelum kunjungan ke rumah sakit. Karena alasan ini pasien dirawat pertama kali di bagian mata, dengan diagnosis saat itu kecurigaan tumor retrobulber. Proptosis sering merupakan gejala dari keganasan, selain akibat keganasan di mata, perluasan dari tumor di sinus maksila merupakan merupakan penyebab terbanyak proptosis di luar tumor mata.13

Sering keluhan utama pasien justru akibat perluasan tumor seperti keluhan mata dan kepala dan bahkan kadang-kadang gejala akibat metastsis jauhlah yang membawa pasien berobat, sedangkan keberadaan tumor sering terabaikan, bahkan oleh petugas kesehatan. ${ }^{2}$ Ini terjadi karena anatomi sinus yang merupakan rongga yang tersembunyi dalam tulang, yang tidak akan dapat dideteksi dengan pemeriksaan fisik biasa. Keadan ini juga menyebabkan tumor stadium dini akan bersifat asimptomatik. Hal ini juga yang membuat diagnosis ditegakkan setelah tumor mendestruksi struktur sekitarnya.,3

Setelah dilakukan pemeriksaan CT Scan orbita, tampak massa pada sinus paranasal kanan yang telah meluas ke orbita dan intrakranial. Pasien dengan tumor sinus paranasal biasanya datang berobat pada stadium yang sudah lanjut, dan umumnya sudah meluas ke jaringan sekitarnya. Kedaan ini merupakan faktor penyebab buruknya prognosis keganasan sinonasal. Secara anatomi sinus paranasal merupakan struktur dan rongga yang sangat erat hubungannya dengan struktur vital di sekitarnya seperti otakotis dan arteri kar. ${ }^{2,3}$

Hidung tersumbat merupakan keluhan yang sering, dan menandakan tumor telah keluar ke kavum nasi atau mendorong dinding medial sinus. Rasa kebas di wajah sudah dirasakan pasien selama tiga bulan. Kebas atau hipostesia di wajah harus dicurigai adanya perluasan suatu keganasan. Selain itu pada pasien ini juga terdapat gangguan visus dan fungsi otot ektraokuler serta nyeri pada gigi atas. ${ }^{1}$

Keganasan sinus paranasal jarang bermetastsis baik ke kelenjar getah bening maupun metastasis jauh, karena tumor berada pada suatu struktur tulang yang kokoh, kecuali telah mendestruksi organ sekitarnya. Tumor di sinus paranasal juga dapat sebagai metastasis dari tumor primer di tempat lain, meskipun ini jarang, dilaporkan dapat metastasis dari keganasan di ginjal, payudara dan paru. ${ }^{1}$

\section{Daftar Kepustakaan}

${ }^{1}$ Carrau RL, Myers EN. Neoplasms of the Nose and Paranasal Sinuses. In : Bayley BJ, Calhoun $\mathrm{KH}$, eds. Head and Neck Surgery-Otolaryngology, $3^{\text {th }} \mathrm{ed}$, Vol.2. Philadelphia: Lippincott Williams \& Wilkins; 2001.p.1247-65.

${ }^{2}$ Armiyanto. Keganasan Hidung dan Sinus Paranasal. In: THT FKUI. Penanganan Mutakhir Kasus Telinga Hidung Tenggorok. Jakarta: THT FKUI; 2003.p. 6078.
Pada pasien ini dicurigai terdapat metastasis jauh ke paru, yang menyebabkan gejala hemoptisis massif . Salem L dkk seperti dikutip Smith GA dkk melaporkan kejadian metastasis ke paru sebanyak $2,6 \%$ dan metastasis ke tulang $1,94 \%$ pada keganasan sinonasal. New GB seperti dikutip Smith GA dkk15 juga melaporkan bahwa paru merupakan lokasi metastasis jauh yang paling sering selain juga dapat ke pleura, hepar, perikardium, ginjal, limpa dan tulang belakang. 15 metastasis ke paru dapat berupa endotracheal/endobronchial metastases (EEM). Pada kasus adanya EEM sering juga disertai dengan metastasis jauh pada tempat lain, seperti dilaporkan Kiryu T dkk ${ }^{21}$ yang menemukan 9 dari 16 kasus (56.3\%) juga terdapat metastasis jauh ekstra bronkial.

Setiap keganasan hidung dan sinus paranasal harus dilakukan biopsi untuk menegakkan diagnosis definitif. ${ }^{2,3,6}$ Dilanjutkan dengan penetuan sadium (staging) tumor. Pada kasus ini biopsi tertunda karena keadaan fisik pasien yang lemah dan penyulit lain yang tidak memungkinkan untuk dilakukan biopsi segera.

Penatalaksanaan tumor tergantung beberapa faktor seperti stadium tumor, histopatologi, lokasi dan perluasan, kedaan umum pasien. Pembedahan dan radioterapi masih merupakan modalitas utama pada keganasan hidung dan sinus paranasal. Sedangkan kemoterapi umumnya digunakan sebagai terapi paliatif. ${ }^{1,2,17}$

Prognosis keganasan sinus paranasal sampai saat ini masih buruk, karena umumnya pasien datang pada stadium lanjut, sampai beberapa dekade terakhir belum tampak peningkatan yang bermakna terhadap angka bertahan hidup pada seluruh keganasan hidung dan sinus paranasal. ${ }^{2,} 14,19,20$

Masih dibutuhkan konfirmasi histopatologi tumor dan konfirmasi adanya metastasis paru, meskipun secara klinis sudah jelas terdapat tanda keganasan. Apabila histopatologi menunjukkan suatu keganasan dan lesi di paru sudah dikonfirmasi sebagi metastasis jauh dari tumor, maka kasus ini sudah berada pada stadium IVC, dengan ukuran tumor yang telah meluas ke intrakranial (T4b) dan adanya metastasi jauh ke paru (M1).

Pada pasien ini juga terdapat berbagai penyulit yang memperburuk keadaan diantaranya adanya riwayat tuberkulosis paru, bronkopneumoni, Ventrikular Ekstra Sistole (VES) dan massa tumor yang telah mendestruksi organ sekitarnya dan bahkan sudah sampai ke serebral serta kecurigaan metastasis ke paru yang menyebabkan hemoptisis massif.

${ }^{3}$ Domanowski G. Malignant tumors of the Sinuses. Diakses dari

http://www.emedicine.com/ent/topic254.htm, last updated May 30, 2006.

4 Fadil M. Diagnosis Dini Tumor Hidung dan Sinus Paranasal. Dalam : FK UKI. Penatalaksanaan Penyakit Hidung Masa Kini. Jakarta: FK UKI, 2004: 1-5

${ }^{5}$ Wong RJ, Kraus DH. Cancer of the nasal cavity and paranasal sinuses. In: Shah JP, Patel SG, eds. Cancer of the Head and Neck. London: BC Decker Inc;2001.p.204-22 
${ }^{6}$ Shao W. Malignant tumors of the Nasal Cavity. Diakses dari http://www.emedicine.com/ent/topic252.htm, last updated June 5, 2006

${ }^{7}$ Barnes L, Tse LLY, Hunt JL, Gensler MB, Curtin HD, Boffeta P. Tumours of the Nasal cavity and paranasal sinuses: Introduction. In: Barnes L, Eveson JW, Reichart P, Sidransky D. Patology and Genetics of Head and Neck Tumours. Lyon: IARC Press;2005.p.12-7

${ }^{8}$ Schantz S, Harrison LB, Forastiere AA. Tumors of the nasal cavity and paranasal sinuses, Nasopharynx, oral cavity and oropharynx. In: Devita VT, Hellman S, Rosenberg SA. Cancer: Principles and Practice Oncology, $6^{\text {th }}$ ed. Philadelphia: Lippincott William\&Wilkins;2001

9 . Chaboki H, Wanna GB, Westreich R, Kao J, Packer $\mathrm{SH}$. Carcinoma of the Nasal Cavity and Paranasal sinus. In: Genden EM, varvares MA. Head and neck Cancer. New York: Thieme;2008.p.118-36

10 Lund PJ. Distant Metastases from Sinonasal Cancer. ORL 2001;63:212-3.

11 Greene FL, Page DL, Fleming ID. AJCC Cancer Staging Handbook 6th Ed. Springer Verlag;2002.

${ }^{12}$ Averdi R, Endang M, Damayanti S. Tumor Hidung dan Sinus Paranasal. Dalam :Efiaty AS, Nurbaiti I. Buku Ajar Ilmu Kesehatan THT Kepala Leher. Jakarta: Balai Penerbitan FKUI; 2003.p.143-5

${ }^{13}$ Sabharwal KK, Chouhan AL, Jain S. CT Evaluation Of roptosis. Ind J Radiol Imag 2006 16:4:683-8.

${ }^{14}$ Cantù G, Bimbi G, Miceli R, Mariani L, Colombo S. Lymph Node Metastases in Malignant Tumors of the Paranasal Sinuses. Arch Otolaryngol Head Neck Surg. 2008;134(2):170-7.

15 Smith Ga, Goldberg S. Bone Metastases in Carcinoma of the Maxillary Antrum. S. Afr Med J 1972;46:1676-8.

16 Lloyd GAS, Lund VJ, Phelps PD, Howard DJ. Magnetic resonance imaging in the evaluation of nose and paranasal sinus disease. British $\mathrm{J}$ Rad 1987; 6:, 957-68

17 Giri SPG, Reddy EK, Gerner LS, Krishnan L, Smailey SR, Evans RG. Management of advanced Squamous Cell Carcinomas of the Maxillary Sinus. Cancer 1992; 69:657-61.

${ }^{18}$ Popović D, Milisavljević D. Malignant tumors of the maxillary sinus. A ten-year experience. Med and Biol 2004; $11: 31-4$

19 Le QT, Fu KK, Kaplan M, Terris DJ, Fee WE, Goffinet DR. Treatment of Maxillary Sinus Carcinoma. Cancer 1999;86: 1700-11.

${ }^{20}$ Lee CH, Hur DG, Roh HJ, Rha KS, Jin HR, Rhee CS, Min YG. Survival Rates of Sinonasal Squamous Cell Carcinoma With the New AJCC Staging
System. Arch Otolaryngol Head Neck Surg. 2007;133:131-4

${ }^{21}$ Kiryu T, Hoshi H, Matsui E, Iwata H, Kokubo M Shimokawa K, Kawaguchi S. Endotracheal/Endobronchial Metastases. Chest $2001 ; 119: 768-75$. 